\title{
ИЗМЕНЕНИЯ БИЗНЕС-ПРОЦЕССОВ В ОБЩЕСТВЕННОМ ПИТАНИИ И ПРОДОВОЛЬСТВЕННОМ РИТЕЙЛЕ ИЗ-ЗА ЭКОНОМИЧЕСКИХ ПОСЛЕДСТВИЙ ПАНДЕМИИ
}

\author{
(c) 2020 Куликов Валентин \\ основатель онлайн-супермаркета Bringston, Россия, Москва \\ E-mail: V@bringston.com
}

\begin{abstract}
В данной статье рассматривается влияние пандемии COVID-19 на бизнес-процессы в сфере продовольственного ритейла и общественного питания. Коррекция подходов к логистике, управлению персоналом, массированная цифровизация и развитие новых форм взаимодействия с клиентами все это проявилось в ритейле и общепите в последние полгода.
\end{abstract}

Ключевые слова: пандемия, ритейл, продовольственный ритейл, общепит, цифровизация, удаленная работа, безопасность, онлайн-заказы, доставка

Пандемия коронавируса, ставшая российской реальностью в марте 2020 года, кардинально повлияла на все сферы бизнеса. «На передовой» оказались области, непосредственно связанные с оказанием потребительских услуг, в том числе общепит и продовольственный ритейл. Вызовы, с которыми эти сферы столкнулись в начале ввода ограничений, были разными. Ритейл переживал характерную для любого общественного стресса временную смену потребительских приоритетов.

В марте, например, заметно выросли - на $23 \%$ - продажи туалетной бумаги и влажных салфеток (+55\% по сравнению с февралем) [1].

Скачок продаж наблюдался в целом по всем товарным группам и был вызван страхом заражения (люди реже посещали магазины и закупались наперед), роста цен и дефицита. По словам директора по инновациям X5 Retail Group Ивана Мельника, после начала карантина рост спроса на замороженные продукты в магазинах компании вырос в 30 раз, на мясные консервы - в 36 ра3 [2].

Имели место и скачки по отдельным позициям, спровоцированные спекулятивными слухами. В течение марта, к примеру, цены на корень имбиря выросли почти в пять раз, с 340,25 р до 1525,72 р. за килограмм [3].

В ситуации ажиотажного спроса торговые сети были вынуждены оперативно менять - или как минимум корректировать - отлаженные бизнес-процессы.

В первую очередь это касалось логистики, формирования дополнительных запасов. Кроме того, нужны были значительные средства на ор- ганизацию условий безопасности - закупку санитайзеров, масок.

Требования безопасности оказали влияние на подход к общению клиентов и персонала. Для минимизации этих контактов продовольственный ритейл начал внедрять (и весьма успешно) кассы самообслуживания в торговых залах (технология scan \& go, позволяющая покупателю самостоятельно сканировать все товары и не стоять на кассе).

А в сентябре X5 Retail Group тестировала в своих торговых точках в Москве (было охвачено 90 магазинов) технологию самостоятельных покупок с помощью мобильного приложения. Чтобы совершить покупку, посетитель сканировал QR-код, размещенный при входе в магазин, затем отсканировать штрих коды тех товаров, что намерен был купить, далее - для расчета - сканировать на выходе из магазина еще один QRкод и наконец, произвести оплату с помощью либо карт, либо сервисов Apple Pay и Google Play. Подобный подход интересен ритейлеру не только с точки зрения безопасности покупателей (которые вообще не вступают в контакт с кассирами и персоналом в торговом зале), но и в смысле минимизации своих расходов на фонд оплаты труда персонала.

Еще одна важнейшая задача, которую приходилось решать ритейлерам - перевод большей части персонала (бухгалтерия, менеджмент) на удаленную работу. Это требовало серьезной перестройки технологических условий работы дополнительных инвестиций в облачные решения и т.д.

Другой важнейший аспект новой COVID-pe- 
альности - бурный рост онлайн-продаж и этого направления в целом. Потребитель, напуганный эпидемией, обратил внимание на подобные сервисы. Бизнес реагировал по мере сил. В апреле, по данным исследования AdvantShop, количество новых онлайн-магазинов в России выросло на 99\% по сравнению с периодом январь-март [4].

Такая же динамика наблюдалась и в продовольственном онлайн-ритейле. Если до пандемии доля онлайн в продовольственном ритейле была очень незначительной, то в марте она выросла вдвое, говорил председатель правления Ассоциации экспертов рынка ритейла Андрей Карпов [5].

Внедрение и развитие системы онлайнзаказов и доставки, как и организация удаленной работы для части персонала, стимулировало цифровизацию бизнес-процессов - усовершенствование приложений, адаптации их к любым видам гаджетов, обеспечения стабильной работы этих приложений и собственных сайтов.

Развитие системы доставки, в свою очередь, требовало и разработки новых логистических решений, и расширения курьерской базы. При необходимости ритейлеры стали обзаводиться партнерами - колл-центрами, агрегаторами доставки, взялись расширять поле игры. X5 Retail, например, кроме сервисов доставки из Пятерочки и Перекрестка, планирует развивать экспресс-доставку «Около». Операционная модель «Около» (о запуске объявили в июле) базируется на партнерстве с малыми компаниями, работающими в сфере экспресс-доставки. Ритейлер сообщал, что на начальной стадии развития «технологическая платформа и сервис «Около» будет ориентирован только на доставку из торговых сетей X5, в дальнейшем к сервису могут быть подключены другие участники рынка еды» [6].

Временный всплеск продаж в самом начале карантина сменился ожидаемым летним снижением показателей в сфере продовольственного ритейла. При этом, что важно, многие отработанные весной бизнес-схемы остались в действии, будь то онлайн-каналы и удаленный формат для части персонала. Значительный процент сотрудников офисов «Ленты», например, останется в удаленном режиме до конца текущего года. В перспективе - введение гибридного режима, предполагающего совмещение удаленной работы и появления в офисе. При этом большинство переведенных на онлайн-режим сотрудников признаются, что полностью адаптировались к такому формату [7].

В отличие от продовольственного ритейла сфера общепита оказалась на грани выживания. Ключевой принцип общепита - обслуживание клиента только на своей территории (в ресторане, кафе и т.д.) - стал не востребован. Спасти рестораны и кафе от гибели могли в первую очередь онлайн-заказы и доставка.

В этой патовой ситуации нужно было организовать все рабочие процессы так, чтобы оперативно реагировать на обстоятельства: корректировать меню, перестроиться на доставку, при этом сохранив персонал - превратив, например, официантов в курьеров.

Еще один важный момент - поиски новых направлений, диверсификация услуг. Заведения стали искать дополнительные источники дохода - запускали продуктовые линии и собственные гастрономические лавки, предлагали наборы ингредиентов для быстрого приготовления на дому.

В таких условиях заметно выросла значимость цифровизации процессов, начало меняться восприятие и отношение к онлайн в целом. Сайты и социальные сети прежде использовались для контактов с аудиторией, затем, в период самоизоляции, превратились в инструмент для оформления заказов. Сегодня эти площадки можно использовать для анализа информации, для сбора данных о предпочтениях клиентов, их выбора.

После открытия заведений летом стало ясно, что бизнес будет оптимизировать расходы на перспективу. «Под нож» пошла часть позиций меню (наименее востребованные блюда), траты на обновление интерьеров и посуды, расходы на персонал. Охрана, PR-отделы, состав официантов попали под сокращение. Тренд на оптимизацию повысил спрос на сотрудников, способных работать в режиме мультизадачности - например, поваров, умеющих делать все. 


\section{Библиографический список}

1. «ОФД Такском: туалетная бумага - хит продаж» https://retail-loyalty.org/news/ofd-takskom-tualetnayabumaga-khit-prodazh/

2. «COVID сломал барьер»: как пандемия ускоряет технологии ритейла» https://sber.pro/publication/spasibocovid-on-slomal-barer-kak-pandemiia-uskoriaet-tekhnologii-riteila

3. «Цены на имбирь в РФ выросли в три раза на фоне роста спроса из-за коронавируса» https://www.interfax. $\mathrm{ru} / \mathrm{russia} / 702280$

4. Аналитика по онлайн-продажам в период карантина https:/www.advantshop.net/blog/common/ analitika-po-onlain-prodazham-v-period-karantina?fbclid=IwAR2kEirS64VAStKVl-jkbzxbAeW-5i95h4sNtzhXTLWRwxYr77smt1tXYw

5. «Озолотиться на коронавирусе. Ждет ли ритейлеров сверхприбыль на гречке и рисе?» https://1prime.ru/ business/20200319/831109146.html

6. «X5 запускает сервис экспресс-доставки «Около» https://www.x5.ru/ru/Pages/Media/News/070720.aspx

7. «Более 80 процентов сотрудников Ленты адаптировались к дистанционной работе» https://retail-loyalty. org/news/bolee-80-protsentov-sotrudnikov-lenty-adaptirovalis-k-distantsionnoy-rabote/ 